\title{
Analysis on the Trading Path of Carbon Emission Rights of Village-level Photovoltaic Poverty Alleviation Power Stations in China
}

\author{
Meng Shoudong ${ }^{1} \quad$ Xie Xiangying ${ }^{2} \quad$ Bai Xue $^{2} \quad$ Gao Liang ${ }^{1 *}$ \\ 1.School of Public Affairs, University of Science and Technology of China,He'fei 230026, China \\ 2.State Grid Electronic Commerce CO.,LTD., Xicheng District,Beijing 100053, China \\ * E-mail of the corresponding author: 289163573@qq.com
}

\begin{abstract}
Photovoltaic poverty alleviation is a pioneering initiative in the organic combination of China's poverty alleviation and new energy development. As a landmark project of China's targeted poverty alleviation, it is characterized with rapid effects, steady profits, precise poverty alleviation and environmental-friendliness. Developing the photovoltaic poverty alleviation power station project into a greenhouse gas emission reduction project that meets the national requirements is not only an innovative measure to consolidate and expand the achievements of poverty alleviation, and continuously promote rural revitalization, but also an effective way to practice green and low-carbon development and promote "Carbon Peak•Carbon Neutrality". Based on the summaries and analysis of the development of China's photovoltaic poverty alleviation and carbon trading market and the situation of carbon emission trading pilot, this paper sorts out the relevant policies of poverty alleviation's participation in carbon trading, studies the participation mode and trading process of village-level photovoltaic poverty alleviation power station, scientifically calculates the additional economic benefits brought by Chinese Certified Emission Reduction (CCER) trading for village-level photovoltaic poverty alleviation power station, and puts forward some policy recommendations on rationally optimizing carbon trading procedures and improving work efficiency.
\end{abstract}

Keywords: Photovoltaic poverty alleviation, Carbon market, Carbon trading, Implementation path

DOI: $10.7176 /$ PPAR/11-5-01

Publication date:June $30^{\text {th }} 2021$

\section{Introduction}

Since 2013, when China set up a card for the poor people, the Party and the country adhered to the precise strategy, fought with all their might, and went all out,Through 8 years of precise poverty alleviation, 5 years of overcoming difficulties, and pooling the strength of the whole country, the fight against poverty was won as scheduled in $2020^{[1]}$. As one of the top ten precision poverty alleviation projects in China, photovoltaic poverty alleviation has played an important role in increasing income and poverty alleviation, ecological protection and new energy development in poverty-stricken areas,It is a pioneering and landmark project for precision poverty alleviation in China. Relevant resources show that the design service life of photovoltaic poverty alleviation power station is generally as long as 25 years, and it is basically zero carbon emission in the whole life cycle, with outstanding ecological advantages ${ }^{[2]}$.

Carbon emission trading was first seen in Kyoto Protocol in 1997, which refers to the trading behavior of market operators buying and selling carbon dioxide emission rights through specific trading mechanisms ${ }^{[3]}$. As a market-oriented mechanism, carbon trading is an important policy tool for China to implement the strategy of energy conservation and emission reduction and promote the construction of ecological civilization. Developing the photovoltaic poverty alleviation power station project into a greenhouse gas emission reduction project that meets the national requirements is not only an innovative measure to expand the achievements of poverty alleviation and difficulties tackling and accelerate the overall rural revitalization, but also an effective way to practice the green and low-carbon development route and achieve the goal of "carbon peaking and carbon neutralization" ${ }^{[4]}$.

\section{Basic information}

\subsection{Overview of China's Photovoltaic Poverty Alleviation}

The implementation of photovoltaic poverty alleviation project is an effective means to develop rural clean energy, promote stable income increase, protect and improve the environment, with obvious economic, social and ecological benefits. By the end of 2020, the installed capacity of China's photovoltaic poverty alleviation power stations has reached more than 18.6 million kilowatts, of which the village-level photovoltaic poverty alleviation power stations are more than 15 million kilowatts ${ }^{[5]}$. Through the online sales of photovoltaic poverty alleviation power stations, the poverty alleviation targets will continue to gain benefits and effectively accelerate the poverty alleviation and difficulties tackling process. 
Photovoltaic poverty alleviation makes full use of the favorable conditions of sufficient light and rich land in poverty-stricken areas to develop electric energy and inject natural resources into clean energy development,At present, the installed capacity of photovoltaic poverty alleviation power stations accounts for nearly one tenth of the total installed capacity of photovoltaic power plants in China, and the cumulative power generation is about 40 billion $\mathrm{kWh}$, which is equivalent to reducing carbon dioxide and nitrogen oxide emissions by more than 37 million tons in the same period ${ }^{[6]}$, boosting the new energy revolution, which is another achievement of photovoltaic poverty alleviation.

\subsection{Overview of China's carbon trading market development}

In October 2010, the document of the State Council first mentioned the trading of carbon emission rights. In October 2011, the National Development and Reform Commission launched carbon trading pilot projects in seven provinces and cities including Shanghai. According to statistics, in 2014, online transactions were launched in 7 pilot areas, involving enterprises with a total carbon emission of about 1.2 billion tons ${ }^{[7]}$. In April 2018, the national carbon market authority was adjusted from the National Development and Reform Commission to the Ministry of Ecology and Environment. Before the end of June 2021, the national unified carbon emission trading platform will land in Shanghai, and the carbon quota registration system will be located in Wuhan, Hubei Province. According to statistics, from the pilot in 2011 to November 2020, the value of carbon trading in the pilot areas nationwide was about 10 billion yuan. With the formal implementation of the Measures for the Administration of Carbon Emissions Trading (Trial), it can be predicted that China's carbon trading market will accelerate its development, and the transaction volume will multiply,By 2030, when the carbon reaches its peak, the transaction volume will exceed 100 billion yuan ${ }^{[8-9]}$.

The carbon trading market is divided into "carbon emission quota" and "carbon emission reduction target". Carbon emission quota is the annual total carbon emission quota issued by the state or local government to high energy-consuming enterprises (emission control enterprises). If the total annual carbon emissions of high energyconsuming enterprises actually exceed this quota, they need to purchase quota indicators from the carbon trading market, and the process is called carbon emission quota trading. At the same time, the excess emission control enterprises can also purchase carbon emission reduction targets through the carbon trading market, so as to offset the excess carbon emissions.

Carbon emission reduction targets mainly come from projects with energy saving and emission reduction effects, such as renewable energy projects including photovoltaic power generation, rural biogas utilization projects, forestry carbon sink projects and so on. In the process of production and operation, these projects realize energy saving and emission reduction, and their energy saving and emission reduction effects are converted into carbon dioxide emission reduction, that is, carbon emission reduction targets. There are two kinds of carbon emission reduction targets, one is "local carbon emission reduction target". Local carbon market authorities may allow energy-saving and emission-reduction projects within their jurisdiction to apply for carbon emission reduction targets according to certain requirements, The carbon emission reduction targets assessed and recognized by local carbon market authorities are local-level carbon emission reduction targets, which are currently only applicable to carbon market transactions in pilot areas. Another carbon emission reduction target is "China Certified Voluntary Emission Reduction (CCER)". According to the national regulations, the carbon emission reduction that the project owner can apply to the Ministry of Ecology and Environment according to the process and is evaluated and recognized is CCER, which can be applied to the national carbon market transactions ${ }^{[10]}$.

\subsection{Pilot situation of carbon trading in China's photovoltaic poverty alleviation projects}

In 2020, Aohan Banner, Chifeng City, Inner Mongolia Autonomous Region took the lead in launching the carbon trading pilot project of photovoltaic poverty alleviation projects in the whole country, At present, the feasibility study and path scheme design of village-level photovoltaic poverty alleviation power stations participating in CCER carbon trading pilot project have been completed, the project identification work has been completed based on the monitoring system, and the project validation and related methodology formulation work are being carried out ${ }^{[11]}$. Through the pilot project, explore the carbon trading path of photovoltaic poverty alleviation projects, and provide reference for the carbon trading of photovoltaic poverty alleviation projects in other regions of China. In addition, China's Guangdong, Shaanxi, Heilongjiang, Qinghai, Hubei and other provinces are also actively piloting the participation of village-level photovoltaic poverty alleviation power stations in carbon market transactions.

\section{Village-level photovoltaic poverty alleviation power station participation mode}

\subsection{Policies and requirements related to poverty alleviation and participation in carbon trading}

In October 2016, the state proposed to actively promote "low-carbon poverty alleviation" and encourage and support poor areas to vigorously develop carbon emission reduction projects ${ }^{[12]}$. In January 2018 , the state 
requested to explore innovative compensation methods for carbon trading and strengthen support for poor areas [13]. In January 2019, the state requested to establish and improve the carbon market offset mechanism ${ }^{[14]}$. In November 2019, the former responsible comrades of the Poverty Alleviation Office of the State Council asked all localities to explore the trading mode of photovoltaic poverty alleviation power stations participating in the carbon market at the national video conference on photovoltaic poverty alleviation work, and use the proceeds from the sale of carbon emission reduction indicators to increase the income of photovoltaic poverty alleviation power stations and create new exploration and new application of carbon emission reduction of photovoltaic poverty alleviation power stations ${ }^{[15]}$.

\subsection{CCER project development mode}

Village-level photovoltaic poverty alleviation power stations can participate in the carbon market in two ways, One is to apply for carbon emission reduction indicators from the Ministry of Ecology and Environment, which is suitable for national carbon market transactions; The other is to apply for local-level carbon emission reduction targets from the ecological environment department of the pilot area, and only deal with the carbon market in the pilot area. It will bring extra economic benefits to photovoltaic poverty alleviation power stations by selling carbon emission reduction targets on carbon trading platforms in the whole country or in pilot areas. Traditional CCER development includes six steps, which are: project identification, project filing application, validation and registration, emission reduction filing application, verification and issuance, and transaction, with an average development period exceeding one year.

\subsection{Development needs of village-level photovoltaic poverty alleviation power stations}

There are significant differences between village-level photovoltaic poverty alleviation power stations and general commercial photovoltaic power stations, which have the basic characteristics of many points, wide areas and dispersion, The traditional offline project development mode brings great difficulties to materials forensics, on-site visits, emission reduction monitoring and other work, resulting in increased project development costs, prolonged cycle, and greatly reduced significance of assistance and emission reduction of photovoltaic poverty alleviation power stations.

\subsection{Village-level photovoltaic poverty alleviation power stations participate in carbon trading mode}

At present, based on blockchain technology, the carbon trading function module of the National Photovoltaic Poverty Alleviation Information Monitoring Center provides one-stop services for the whole process of CCER project online signing, online material collection, online agent packaging, online data verification and income distribution (See figure 1 for the overall development model of CCER project in China), providing efficient and convenient platform data services for decentralized village-level photovoltaic poverty alleviation power stations, ensuring credible and controlled carbon trading of power stations, and shortening the project development time to $8-12$ months.

\section{Revenue measurement and implementation path \\ 4.1 Income calculation}

Since the pilot implementation in 2013, the annual average price of CCER has increased significantly from 11 yuan/ton in 2014 and 2015, to 8 yuan/ton in 2016, and then to $6 \sim 10$ yuan/ton in 2017 and 2018, and it is about 20 yuan/ton in 2020, showing an upward trend of fluctuation. Since the implementation of the photovoltaic poverty alleviation project in 2014, more than 1,400 counties in 27 provinces (autonomous regions) in China have built village-level photovoltaic poverty alleviation projects of about 15 million kilowatts, which can deliver 15 billion kilowatt hours of clean energy to the whole country every year during the life cycle of the power station, which will reduce the emission of carbon dioxide by 12 million tons, According to the 20 yuan/ton carbon price, 240 million yuan can be added every year to consolidate and expand the achievements of poverty alleviation and difficulties tackling. At present, among the 1.65 million kilowatts of photovoltaic poverty alleviation power stations in Inner Mongolia, there are 650,000 kilowatts of village-level photovoltaic poverty alleviation power stations, which are calculated according to the average annual equivalent utilization hours of about 1,625 hours ${ }^{[16]}$ and the on-grid power generation of 1.06 billion $\mathrm{kWh}$ in 2020 ,It is estimated that about 876,000 tons of carbon emission reduction targets will be obtained every year (calculated according to the baseline emission factor of Inner Mongolia Autonomous Region power grid released by the Ministry of Ecology and Environment in $2019^{[17]}$ ), and according to the 20 yuan/ton carbon price, 17.52 million yuan can be added to consolidate and expand poverty alleviation and difficulties tackling every year under the existing conditions, which is equivalent to an increase of 0.017 yuan per kilowatt hour. With the continuous development of the national carbon market, the carbon price will show an upward trend, and carbon trading will have a greater income increasing effect on photovoltaic poverty alleviation projects. 


\subsection{Implementation Path}

Comprehensively promote the photovoltaic poverty alleviation power station to obtain the "dividend" of carbon emission reduction, effectively form a new model and new achievement of consolidating the achievements of poverty alleviation and difficulties tackling and serving the national strategic goal of "carbon reaching peak and carbon neutralization" in the new period, and jointly set up a carbon asset project development team of photovoltaic poverty alleviation power station by provincial poverty alleviation (rural revitalization) departments, third-party consulting institutions, third-party certification and certification institutions and county-level poverty alleviation (rural revitalization) departments in the project area, where all parties cooperate and have complementary advantages, Give full play to the basic data function of the national photovoltaic poverty alleviation information monitoring system and the module function of the carbon trading zone, jointly promote the development of photovoltaic poverty alleviation power stations in the provincial catalogue as CCER projects, and participate in the national carbon market transactions. The specific implementation path of CCER project development and carbon market transaction of village-level photovoltaic poverty alleviation power station is as follows:

4.2.1 Project Start-up

Led by provincial poverty alleviation (rural revitalization) and other departments, the CCER project development plan of photovoltaic poverty alleviation power station in the province was jointly researched and formulated by the carbon asset project development team of photovoltaic poverty alleviation power station, the responsibilities and division of labor of all parties were clearly defined, and the project was organized to start.

4.2.2 Entrusting contract

Provincial poverty alleviation (rural revitalization) departments and related entities signed a commissioned development service agreement with a third-party consulting agency, clarifying that the third-party consulting agency is the authorized entrusting party for project declaration and filing, and has full authority to represent CCER project development; The third-party consulting agency shall bear the development expenses in the early stage of the project, and collect a certain percentage of income according to the specific agreement after the successful transaction of the project.

4.2.3 Pilot research

Third-party consulting organizations went to relevant provinces to investigate the basic situation of photovoltaic poverty alleviation power stations, and sort out the construction, environmental protection, acceptance, power generation and income of photovoltaic poverty alleviation power stations.

4.2.4 Data collection

According to the survey results, the third-party consulting organization collects and sorts out the information, images and application materials of the project owner's power station equipment including county-level poverty alleviation (rural revitalization) departments and investment enterprises, and transmits the relevant data information to the carbon trading function module of the national photovoltaic poverty alleviation information monitoring system for certification.

4.2.5 Project design

Third-party consulting organizations shall prepare filing materials and produce project design documents (PDD) according to the requirements of the national CCER Interim Administrative Measures.

4.2.6 Project examination and approval

Third-party validation agencies rely on the project materials and system data of the National Photovoltaic Poverty Alleviation Information Monitoring System to complete the project validation work in an "online+offline" manner, and issue validation reports and upload them to the carbon trading zone of the monitoring system for certification.

4.2.7 Monitoring and certification

A third-party consulting agency shall prepare a monitoring plan (MR) for carbon emission reduction indicators of photovoltaic poverty alleviation power stations, and jointly with a third-party certification agency, take online certification and necessary offline visits to the project, and issue a certification report and upload it to the carbon trading area of the monitoring system for certification.

4.2.8 Project filing

Submit the application materials for project filing, and complete the carbon emission reduction index project filing after the application materials have passed the expert review organized by the Ministry of Ecology and Environment, the national competent department.

4.2.9 Issuance of emission reductions

After the project is successfully filed, the application materials for carbon emission reduction filing shall be submitted according to the procedures, and the carbon emission reduction targets shall be filed after passing the expert review organized by the Ministry of Ecology and Environment of the competent national department, and the carbon emission reduction targets shall be registered under the name of a third-party consulting agency. 


\subsubsection{Transaction carry-over}

Third-party consulting agencies seek buyers of carbon emission reduction targets to complete the transaction. After the transaction is completed, according to the previous entrustment agreement, the relevant expenses are deducted from the income (generally about $8 \%$ of the income, subject to the actual development agreement), and the remaining funds are transferred to the bank account designated by the project owner by the third-party consulting agency.

\section{Conclusions and policy recommendations}

China's village-level photovoltaic poverty alleviation power stations are widely distributed and numerous, which have significant carbon emission reduction benefits as a whole,Participating in carbon trading has high economic value, but it is difficult for a single power station to participate in carbon trading development, certification, high operation cost and poor economy. In view of this, it is suggested that the relevant competent authorities in China should study and issue policy documents to further support photovoltaic poverty alleviation power stations to participate in the carbon market as soon as possible, and clarify relevant matters, so as to effectively promote the credibility and efficiency of photovoltaic poverty alleviation power stations to participate in carbon trading.

\subsection{Unified authorization}

Taking the provincial level as a unit, the village-level photovoltaic poverty alleviation power station is packaged as a project to apply for carbon emission reduction targets, and an institution is entrusted as a unified application subject.

\subsection{Optimize business processes}

Open a "green channel" for carbon trading declaration of poverty alleviation projects, optimize relevant procedures and data sources, and shorten the application period (originally it was generally one year). According to the actual situation of distributed photovoltaic poverty alleviation power station project, the supporting documents such as power station construction site selection, environmental impact assessment, power generation license and risk assessment shall be exempted from inspection, and the power station construction approval documents may be replaced by the "Village-level photovoltaic poverty alleviation power station construction plan" issued by the local government or poverty alleviation (rural revitalization) and other departments or similar documents.

\subsection{Simplify data acquisition}

In view of the small scale and large number of village-level photovoltaic poverty alleviation power stations, the third-party validation and certification institutions can directly adopt the relevant data of the National Photovoltaic Poverty Alleviation Information Monitoring Center and carry out on-site inspections on some power stations when carrying out project validation and certification.

\subsection{Preferential support for tilt}

Formulate preferential policies to consolidate and expand the carbon emission reduction targets of poverty alleviation and difficulties tackling achievement projects and enter the national unified carbon market, and encourage and guide key emission units in power, steel, chemical and other industries to purchase.

\section{Acknowledgement}

Thanks for the effort of the editor, reviewers and other people, we are appreciated. This Research was supported by the Natural Science Foundation ( L1924080), the Natural Science Foundation of Anhui Province (2008085QG343),The Fundamental Research Funds for the Central Universities (WK2160000010), The USTC Funding for Featured Liberal Arts under Grant（YD2160002008）.

\section{References}

[1] Xi Jinping's speech at the National poverty alleviation and difficulties tackling Summary and Commendation Conference [EB/OL],Xinhuanet, http://www.xinhuanet.com/politics/leaders/2021-02/25/c 1127140240.htm.

[2] Research Report on Cleaner Production of Photovoltaic Industry in China [EB/OL],Sina.com,https://ishare.iask.sina.com.cn/f/62680375.html.

[3] Kyoto Protocol [EB/OL],Sina.com,http://www.ruiwen.com/gongwen/shuxin/195098.html.

[4] Xi Jinping's speech at the general debate of the 75th UN General Assembly [EB/OL],People's Daily Online, http://cpc.people.com.cn/n1/2020/0923/c64094-31871241.html.

[5] Notice of General Department of Poverty Alleviation Office of the State Council, General Department of National Energy Administration, General Department of Poverty Alleviation Office of the State Council 
and General Department of National Energy Administration on Printing and Distributing the Speech of Comrade Liu Yongfu and Zhang Jianhua at the National Photovoltaic Poverty Alleviation Work Site Meeting: Guo Kai Ban Si Fa [2020] No.16.

[6] Wang Jianren,China's solution to solve the world poverty reduction problem: the sun shines on the well-off road [J],China Poverty Alleviation, 2021 (04): 26-33 .

[7] Zhou Jian, Deng Yirong, Zhuang Changwei,Research on the development process, present situation and prospect of China's carbon trading market [J]. Environmental Science and Management, 2020,45(9):1-4 .

[8] Measures for the Administration of Carbon Emissions Trading (Trial) [EB/OL],official website of the Central People's Government of the People's Republic of China, http://www.gov.cn/zhengce/zhengceku/202101/06/content 5577360.htm.

[9] The opening of carbon trading market: those private enterprises that deeply cultivate photovoltaics welcome new opportunities [EB/OL],Sina. https://finance.sina.com.cn/chanjing/cyxw/2021-02-05/docikftpnny4888290.shtml.

[10] interim measures for the management of greenhouse gas voluntary emission reduction transactions [EB/OL],carbon emission trading network,http://www.tanpaifang.com/zhengcefagui/2019/101765890.html.

[11] Inner Mongolia Autonomous Region Innovative Photovoltaic Poverty Alleviation Carbon Trading Broadens the Revenue Channel of Photovoltaic Poverty Alleviation [EB/OL], China Poverty Alleviation Inner Mongolia Channel, http://www.zgfpnmgz.com/jzfp/info_40745.html.

[12] work plan for controlling greenhouse gas emissions during the 13th five-year plan [EB/OL],official website of the central people's government of the people's Republic of China, http://www.gov.cn/zhengce/content/2016-11/04/content_5128619.htm.

[13] ecological poverty alleviation program [EB/OL],official website, state forestry and grassland bureau, http://www.forestry.gov.cn/Zhuanti/content_lqgg/1073059.html.

[14] action plan for establishing a market-oriented and diversified compensation mechanism for ecological protection [EB/OL],official website of the central people's government of the people's Republic of China, http://www.gov.cn/xinwen/2019-01/11/content_5357007.htm.

[15] State Council Poverty Alleviation Office,Speech by Comrade Ou Qingping at the National Video Conference on Photovoltaic Poverty Alleviation.

[16] national distribution map of solar energy resources by province [EB/OL]. Snowball net, https://xueqiu.com/5273839515/160380977.

[17] baseline emission factor of China's regional power grid in 2019 [EB/OL],official website, Ministry of Ecology and Environment, http://www.mee.gov.cn/ywgz/ydqhbh/wsqtkz/202012/t20201229 815386.shtml. 